\title{
CHIRONOMUS - Mitteilungen aus der Chironomidenkunde
}

Such was the title of the first CHIRONOMUS newsletter produced by E.J.Fittkau and F.Reiss in July 1967 - six pages of which nearly four comprised a list of chironomid workers known to the editors arranged alphabetically by nationality. The stated purpose of the newsletter was to enable chironomid workers to publicize their activities, share techniques, to give details of forthcoming symposia and periodically update the directory of those working on Chironomidae. English started to appear in Vol.1 No.7 (1969) and scientific accounts began to be published in Vol 1 No.8 with a paper by P.D.Armitage on 'Chironomid larvae in a lake with a long ice cover period'. Vol. 1 No. 9 (1970) was devoted to an account of the $4^{\text {th }}$ International Symposium on Chironomidae held in Ottawa, compiled by D.R.Oliver, complete with a list of participants, program, titles of papers presented, abstracts and a photograph of participants (all of these have been taken over by more recent symposium organisers and the details ceased to be published in the newsletter). In Vol. 1 No.7 Fittkau announces the forthcoming publication of a comprehensive bibliography on Chironomidae compiled by himself and Reiss with the help of O. Hoffrichter. This was the establishment of an ongoing bibliography updated year on year in the newsletter for years until recently by O. Hoffrichter. Also in that edition was a questionnaire: CHIRONOMUS to remain a newsletter or to become a combined newsletter/ journal? Readers were requested to give an opinion on such an upgrade and to whether they were prepared to contribute to the costs. It has taken 42 years for that vision to be achieved! After nine years volume 1 comes to an end, No.19 being the final part (April 1976) in which it was announced the transfer of the Chironomid Centre from Plön to Munich on $1^{\text {st }}$ May 1976. From 1982 to 1985 the newsletter was edited by Fittkau, Reiss and Jim and Mary Sublette. It ceased publication in 1985.

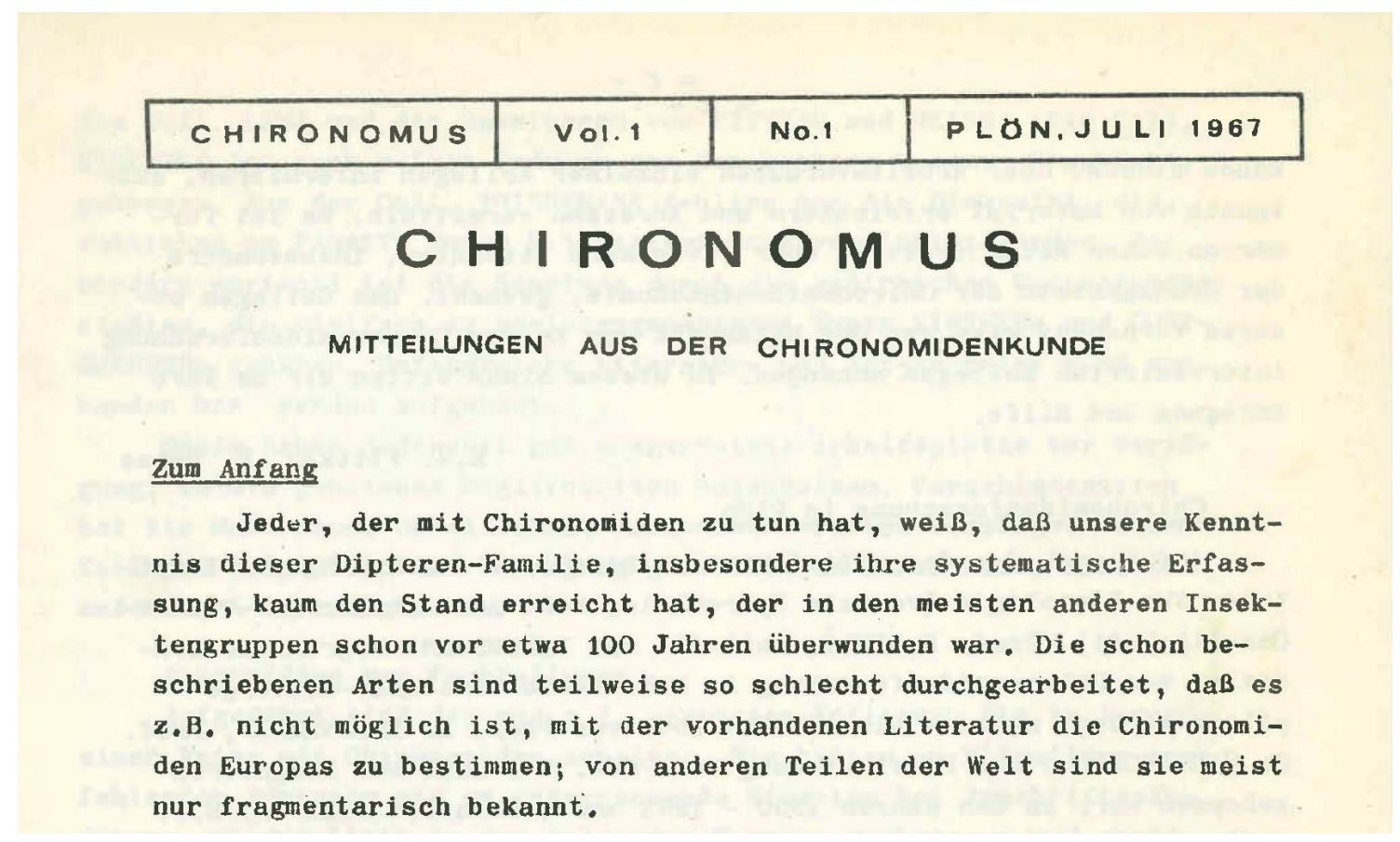

The front page of CHIRONOMUS No. 1

At the Amsterdam Symposium (1991) it was decided to resurrect the newsletter and U. Nolte and R.K. Johnson took on the responsibility. The language changed to English and "Another change in the newsletter's profile is that it excludes contributions with a taste of scientific publication. There are a great number of journals in circulation which offer sufficient opportunities for publishing original scientific data on Chironomidae... but there was a lack of an informal forum for our area of research, and it it is exactly this need that provided for the newsletter's revival." So wrote Nolte in her first editorial (No.4, 1992). The page size had increased and so had the number of pages, which averaged 40 during her editorship. From No.6 (1994) the newsletter contained a Current Bibliography section compiled by O. Hoffrichter and this served to keep the number of pages high for years. During Nolte's editorship it was indeed possible to include lit- 
tle notes of (hopeful) interest to other chironomid workers: I was able to publish two notes in No.7 (1995), one on a chironomid that was observed on the neck of an open bottle of wine, that then dropped off and staggered about as if drunk ('Sixlegged and legless'), the other an account of the construction of a remarkably efficient emergence trap made from a pair of ladies' tights. The pages were embellished with line drawings and cartoons - a magazine for chironomists!

Ulrike Nolte stepped down as editor in 1998 and Ruth Contreras-Lichtenberg and Peter Langton took on the responsibility. Immediately Ulrike's bottom line slipped with the publication of a paper by Burlak, Golygina and Kiknadze on 'Larvae of Chironomus can have a different susceptibility to

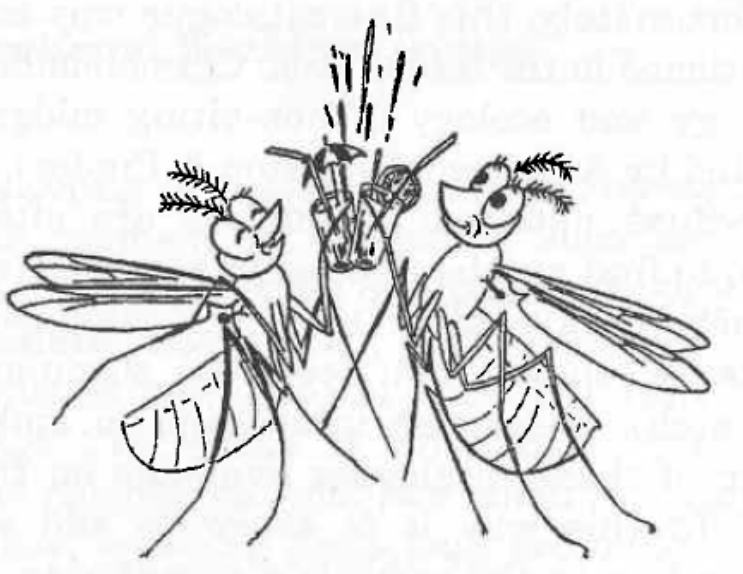

Tipsy chironomids from CHIRONOMUS No. 7

the entomopathogenic bacterium Bacillus thuringiensis subsp. israelensis depending on different inversion genotypes': a paper that could have been published in an established entomological journal. That practice has continued to the present day within a section entitled 'Current Research'.

In 2006 Ruth expressed her wish to step down as editor and Torbjørn Ekrem agreed to succeed her. Colour pictures began to grace the cover of the newsletter and the Current Research section expanded. In 2013 Alyssa Anderson was invited on to the editorial board restoring its transatlantic composition. The stage was set for a transformation. Already papers for inclusion in Current Reearch were being peer reviwed, the newsletter was registered as an open access journal with an ISSN number that is indexed in the Directory of Open Access Journals and Google. The editors felt a change of name was warranted by its new status and at the $19^{\text {th }}$ International Symposium in the Czech Republic a vote was taken and practically all the delegates agreed with a name change to CHIRONOMUS Journal of Chironomidae Research: and that will be the title as of No.28 (2015). Chironomists now are blessed with a more complete Bibliography than for most other insect groups, a comprehensive Directory of Chironomid Workers and now a journal on Chironomidae: all metamorphosing from the original newsletter by 'Sepp' Fittkau and Frieder Reiss. There is much that the chironomist community have to be grateful for to these two stalwarts of our preoccupation.

\section{Peter H. Langton}

16, Irish Society Court, Coleraine, Co. Londonderry, Northern Ireland BT52 1GX.

E-mail: langtonph@gmail.com. 